Open Access

\title{
Open innovation concept: integrating universities and business in digital age
}

\author{
Boris Alexander Becker ${ }^{*}$ and Cornelia Eube
}

\author{
* Correspondence: boris.alexander. \\ becker@gmail.com \\ Department of Empirical Education \\ Research, FernUniversität in Hagen, \\ Hagen, Germany
}

\begin{abstract}
There exists a huge amount of literature with regard to the new openness of firms or universities to trigger innovations. Among others the Triple-Helix approach conceptualizes the role of the state to fulfill the demand of social welfare. The state, universities and private companies together fulfill different values und function according to different rules of the game. In fact, the state disposes of the monopoly of power. Therefore, it is of interest to further elaborate the question of how the state should fulfill its role within this interplay. The purpose of the following paper is therefore to reveal firstly a corresponding research gap and to formulate an answer by referring to organizational formats. By means of a theoretically derived concept according to plausibility considerations the superiority of a network over a hierarchy governmental approach is proclaimed. Secondly, the paper highlights the new demanding and conflicting role of universities with regard to the collaboration with private business companies. Universities as a knowledge supplier fulfil a crucial role within this institutional framework and need to redefine their self-understanding as collaboration with business gains importance. Thirdly Web 2.0 applications within the framework of lifelong learning concepts are being discussed as an adequate tool to fulfil the requirements developed earlier on: The question arises in what way innovative technologies and blended learning can support learning by business people on the one hand and adapt research work of university people to the realistic demands of business on the other. In conclusion some policy implications are derived from this conceptual paper, focusing on the role of intermediary agents and innovative technologies to enhance trust relationships between the different stakeholders and seeking to add useful considerations with regard to innovation policy. The main findings deny a restrictive policy approach. Instead, rather a concept in the sense of help for self-help seems to be fruitful. By means of organizing the innovation policy throughout a sense of "Openness" towards all relevant stakeholders the impetus lies on strengthening the system from the inside. Considering the interests of the stakeholders and subsiding digital formats of learning and knowledge transfer a valuable contribution possibly could be done.

Keywords: Open innovation, Innovation policy, Institutional framework, Lifelong learning, Knowledge transfer
\end{abstract}




\section{Introduction}

The notion of the university as an ivory tower is well known and frequently discussed. Nevertheless, recent research results favour a new "open role" of universities to fulfil their functions as knowledge providers. This rather economicscentred view is subsumed under the term "Open Innovation" by Chesbrough (2008). Companies as important job-providers increasingly operate in a global market defined by vigorous competition. Within this field, knowledge and its circulation become crucial for survival in the market. Due to these demanding circumstances the identification of relevant sources of knowledge has to be paid attention for economic success. One option offers public science or universities as a stakeholder within the national innovation system: According to Fabrizio 'public science supports the productivity of private science in multiple ways' (Fabrizio 2006, p. 136). Empirical studies have explored the fruitfulness of public knowledge for firms in the sense of a leverage effect. For instance access to university knowledge increases the rate of efficiency and effectiveness with regard to innovation outcome. (Cockburn and Henderson 2000). Therefore in the U.S. policy programs have been launched to tie university research to industrial participation and to stimulate economic development. Nevertheless the advantageousness of university research varies across industries and is particular important in high-tech sectors (Cohen et al. 2002).

At the same time universities act as independent stakeholders and follow the paradigm of open 'science' (Poyago-Theotoky et al. 2002). Although the two actors (universities and companies) are in many cases diametrical opposites in the way they handle information and knowledge and in their different structures, constraints, aims and objectives, impetus for a deeper relationship than before does exist (Rayna and Striukova 2015).

The question now arising is how the state can support this desired collaboration and what role digitization performs in the interplay between university and industry. This paper aims to contribute to this discussion by relating theoretically conceptualized demands regarding the "Governance of knowledge-transfer within university-business collaboration" to the offers from new media. To fulfil this task the paper first explores the state of the art in innovation studies and introduces the approach of Network versus Hierarchy as a theoretically derived concept with regard to Innovation Policy and Governance topics. Secondly, in contrast to this macro-level dimension, the paper discusses university-industry collaboration on a micro level. The general framework and its dynamic are revealed and the problem of transferring implicit knowledge and its bondage to personal mobility is discussed. In the following section possible solutions on this track to an open-minded university are proposed, with a special focus on Web 2.0 applications. In fact, digital media might perhaps support the establishment of intermediate actors and have the capacity to build up trust on the micro level alongside measures on the Governance or macro level. Network-oriented Governance together with digitization as a tool may help to overcome the gap between science and industry and lead to lifelong learning and innovation outcome. Following an outline of implications for policy, the paper then concludes with a discussion of its implementation. 


\section{Conceptual approaches explaining differences in innovation outcome}

There exists a broad range of literature referring to the innovation outcome of companies, regions, nations and of a global scale. They in fact have in common a discussion of three central stakeholders involved, namely business companies, knowledge generating institutions like universities and finally governmental entities. This has been summarized by the Triple-Helix approach (Etzkowitz and Leydesdorff 2000), which focuses on the dynamics of this "collaboration" of three stakeholders with different rules of the game. In fact, it represents a clash of different cultures. Nevertheless, the potential of this collaboration has risen mayor attendance among scholars, practitioner's and politicians. Among the concept of the Triple-Helix there exist different approaches with focus on either university-industry collaboration on the micro level or the role of the state on a macro level. In the following this distinction is taken into account and firstly the role of state revealed in more detail. According to Meissner \& Kotsemir, the term "innovation includes new technological, economic, organizational and social solutions which are not necessarily marketable in an economic sense with direct monetary impact but are applied and used" (Meissner and Kotsemir 2016, p. 3).

\section{Innovation policy}

Among other categories the Global Competitiveness Index (GCI) publishes an innovation sub-index every year to measure the innovation outcome of a country and to forecast its innovative performance. This benchmarking functions as a ranking and pinpoints certain failures of countries and their governments respectively. It is therefore of high interest for policy-makers to identify possible reasons for these weaknesses and to foster the innovation outcome. Kaiser (2008) gives an overview of comparative approaches to analyzing highly industrialized countries within the range of Comparative Political Economy. Generally speaking the study by Kaiser (2008) indicates the potential of state-centred innovation policy control to improve the coordination of societal actors and consequently the innovation outcome. Within this context Perkmann \& Walsh (2007) emphasize the role of the institutional setting to stimulate collaboration between universities and enterprises. 'On an institutional level of analysis, much existing literature (...) fails (...) to address how existing institutional structures and national innovation systems shape organizational arrangements for university-industry collaboration' (Perkmann \& Walsh, 2007, p. 274).

Innovation Policy aims to influence the coordination between different stakeholders as well as their interaction with the institutional subsystem (Kaiser 2008). This importance of the coordinating function of the state is accentuated by Chaminade and Edquist (2010) as well in their investigation of a demand-driven innovation policy framework in general: 'In terms of both lack of user-producer interaction and lack of articulation of demand in general, state actors have a role to play' (Chaminade and Edquist 2010, p. 284). This perspective is derived from the national innovation system (NIS) model, which was conceptualized in the 1990s by Freeman (1991), Lundvall (1992) and Nelson (1993). It represents a holistic approach which puts special emphasis on interactions, interconnectedness and synergies (Meissner and Kotsemir 2016).

A national system of innovation is the system of interacting private and public firms (either large or small), universities and government agencies, aiming at the 
production of science and technology within national borders. Interaction between those units may be technical, commercial, legal, social and financial, inasmuch as the goal of the interaction is the development, protection, financing or regulation of new science and technology (Niosi et al. 1993, p. 212).

Possible focal points for state intervention such Research Policy, Financial Policy or Domestic and Judicial Policy can be identified here. Nevertheless, there is no set course to be steered. Instead, the whole system is in constant motion and no one can predict the future or the exact path it will take. The approach calls for policy intervention where problems exist that the private actor cannot solve (Chaminade and Edquist 2010). Although this approach encompasses a wide variety of institutions and actors and stresses the importance of linkages, "the meaning of trust building in the networked innovation and the ways of its achievement (...) as well as the role of governments or its proactive policy creating favourable conditions for such interactions" is undermined (Meissner and Kotsemir 2016, p. 9).

\section{Open innovation}

Alongside the approach of the NIS, which argues mainly on an institutional level, there exists the Open Innovation (OI) approach (Chesbrough et al. 2006). This also needs to be considered to formulate adequate Innovation Policy. Whereas the approach of the NIS treats enterprises as a black box, the OI approach investigates the perspective of enterprises. For Fabrizio (2006), as one of the pioneers of the OI approach, Open Innovation means 'the purposive inflows and outflows of knowledge to accelerate internal innovation, and expand the market for external use of innovation, respectively' (Fabrizio 2006, p. 134). Gassmann and Enkel (2006) distinguish between three forms of cooperation processes - firstly 'Outside-In', in which the exploitation of external knowledge resources is subsumed as customers, suppliers and other institutions like universities provide the enterprise with inflows of knowledge, and secondly 'Inside-Out', which means the external commercialization of internal knowledge such as new product ideas or brands. Thirdly the term 'Coupled-Process' is used to characterize innovation networks. In this case both 'Outside-In' and 'Inside-Out' strategies are connected by means of strategic alliances to fulfil the demands of the market (Gassmann and Enkel 2006). Consequently the places of knowledge generation, technological realization and market commercialization must be distinguished.

Summing up the point of interest of the OI approach moves away from industry as the only actor in accordance with the NIS approach. Instead, knowledge generation is considered as a fully integrated process with many important actors and sources of knowledge becoming involved (Fabrizio 2006). The OI approach as well as the NIS approach accentuate the advantage of outsourcing knowledge-generating processes, although both approaches stem from different perspectives. Moreover the intervention of the state or public sector is suggested by both approaches. In fact De Jong et al. (2008) formulate this conclusion by saying, 'However, when universities or public research institutes are involved, such relations are coordinated to a limited degree by the market mechanism' (de Jong et al. 2008, p. 39). Nevertheless, the two approaches do not answer the question of how the state or innovation policy has to be conceptualized in order to support innovative performance in the sense of outsourcing knowledge- 
generating processes. According to Werle (2012), 'one central shortcoming of studies pertaining to national innovation systems is their lack of a theoretical concept of institutions that could be related to and integrated with general institutional theory' (Werle 2012, p. 29). But it is institutions and their specific configuration which decide on the differences in the innovative style of each country. Therefore society's institutions should first be examined before attempting any forecast of their influence on innovative performance (Hollingsworth 2000).

\section{Network versus hierarchy approach}

The previous discussion has elaborated the research gap and differentiated the point of interest with regard to boosting the innovation outcome of a country. The latter aspect with regard to institutions can be subsumed under the term governance, which is defined as the 'totality of institutional arrangements -including rules and rule-making agents - that regulate transactions inside and across the boundaries of an economic system' (Hollingsworth et al. 1994, p. 5). In fact there are many different types of institutions, which interact in a specific way, modulate governance models and modify the mode of knowledge transfer (Ortiz 2013). According to Hollingsworth et al. (1994), it is possible to distinguish between the market, the organization, the state, the network, the community and the association. The characteristics of each form cannot be discussed in detail in this paper. Instead, the paper aims to contribute to the debate and help close the research gap with regard to the advantages of specific institutional configurations for the purpose of cross-border knowledge transfer in the sense of the above described outsourcing of knowledge generating processes. The two opposites in the continuum of institutional configurations are therefore discussed below and the network versus hierarchy approach is introduced. On the one hand a network 'describes stable relations and interactions of persons or organizations, without that the actors lose their autonomy' (Ortiz 2013, p. 39f). Those actors are neither an integrated part of a formal organization nor completely autonomous as in a market. Instead, the connection within a network has a sustainable but loose character and is therefore predisposed to exchanging resources, which are not precisely costed and therefore cannot be purchased on the free market (Lütz 2006). To the best of our knowledge, network studies are quite rare within the context of governance of the innovation system. Studies drawn from management fields, which explain the innovative performance of firms, are much more widespread. According to van Rijnsoever et al. (2014), these studies underline the preponderance of networks within firms to establish new forms of resource or knowledge combinations, which lead to new innovation. Therefore these studies suffer from the enterprise focus, since innovation outcome within the whole innovation system is not considered. Moreover this research strand does not "justice the innovation system premise that new inventions and technologies are the outcome of collaboration between different actor types" (van Rijnsoever et al. 2014, p. 1095). Apart from this, there are network studies in the literature on innovation systems, which focus their research on the dynamics of regional networks (e.g. (Yokura et al. 2013).

In this paper the network versus hierarchy discussion is conducted with regard to the governance level. Normally the state is considered as hierarchically structured, since it disposes of the monopoly of power to enforce new laws or other decisions (Ortiz 2013). The hierarchical organization is predisposed to fulfil complex tasks, as each unit's role is 
defined by its power limitations and task-sharing is common. This leads to the predictability of action and capacity to act (Benz and Dose 2010). Nevertheless, this also hampers coordination between different actors within a hierarchically structured organization. According to Benz and Dose (2010), this is the case because the leadership and the various subdivisions of such an organization do not pursue the same aims. Therefore the building up of trustful relationships as a condition for long-lasting coordination processes becomes difficult. Generally speaking, it is possible to distinguish between interaction, coordination and stability of a relationship. Whereas interaction is a necessary condition for knowledge transfer, the level of coordination is reached through the exchange of information and resources. Therefore coordination is the sufficient condition for knowledge transfer Becker (2014). Benz and Dose (2010) point out that these conditions do not allow any forecasts of the stability of this relationship. In this case trust as an independent variable comes into play. Without trust, no lasting exchange of tacit knowledge materializes and trust goes along with shared norms and values, as well as with common aims (Benz and Dose 2010). Various literature contributions exist about trust and its function within networks, which Newell and Swan (2000) elaborate very well. Alongside shared norms and values, the development of trust may be process-based in the sense of reciprocal recurring exchange, or be traced back to social similarity (Zucker 1986).

To summaries this section, the network versus hierarchy approach encompasses different governance models on the macro level, which move in the continuum between the network as beneficial for knowledge transfer on the micro level and hierarchy as inhibiting or hampering knowledge transfer on the micro level.

\section{Cooperation between universities / research institutes and private enterprises}

The following section deals with the previously mentioned micro level in more detail. In fact certain obstacles with regard to the knowledge transfer between universities and private enterprises are discussed.

\section{General framework and its dynamics}

Generally speaking, the aims and interests of researchers and entrepreneurs differ. On the one hand researchers seek to develop a scientific reputation based mainly on publications, and on the other hand entrepreneurs need to look after their sales and corresponding profits. The two sides and their potential for cooperation are first discussed theoretically in this section. To start with the general motives of researchers and entrepreneurs have to be examined, since without overlapping interests there will be no sustainable and successful cooperation (Lee 2000). Lee (2000) has evaluated the general conditions for cooperation by means of 400 case studies and concludes that researchers follow classic scientific goals (Worasinchai et al. 2008). The commodification of scientific results plays a minor role. Instead, researchers seek financial resources to support their research work and build up a well-equipped laboratory. Moreover researchers are interested in testing their theories and conclusions under empirical conditions and thus expanding their scientific knowledge. Further motives for cooperation with the private sector are supporting the transfer of human capital to industry. It is obviously of interest for researchers to arrange job opportunities for their students. By contrast, industry and business follow different goals in cooperation with the scientific world. In the first place private companies are searching for possibilities to improve their products and to launch highly profitable innovations. 
Therefore the applicability of the research performed by scientists is of higher interest for enterprises. Consequently the expansion of their general knowledge by means of seminars or workshops plays a minor role (Lee 2000).

Given this situation, different models have been developed in the literature to filter out the promoting factors for and the obstacles to successful cooperation between the scientific and business worlds (Worasinchai et al. 2008). Hermans and Castiaux (2007) for example examine whether the process of internal knowledge creation is influenced by external cooperation at all. Since both stakeholders, universities and enterprises, aim to generate new knowledge by means of cooperation, this question is highly relevant. Based on a qualitative research design, the authors investigate knowledge exchange between different stakeholders and its consequences for the aim of knowledge creation. They describe the process as a helix, which resembles the 'four modes of knowledge conversion' by Nonaka (Nonaka et al. 2000).

The first step is the level of socialization, when the different parties get to know each other and exchange firstly implicit knowledge (Nonaka et al. 2000). Due to a cultural gap based on the different motives and interests described above, this process of enhancing trust between the stakeholders becomes difficult. Nevertheless, according to Hermans and Castiaux (2007) a solution exists. A third party should act as technological mediator, assuming the role of broker, and contribute to trust and credibility building. However, this should take place discreetly, since the socialization process is usually based on informal contacts, and official fairs or formalized events fail to deliver the desired outcomes.

The level of externalization follows, by means of which a formalized agreement is reached. Based on the preceding informal contacts and the tacit knowledge exchanged about the partners' beliefs and positions, the knowledge is codified for the first time (Nonaka et al. 2000). This goes along with pros and cons for the knowledge exchange. Based on case-study results by Barnes et al. (2002), Hermans \& Castiaux proclaim that 'the physical evidence of confidential agreements enhance the commitment of individuals working on the project and act as a mediator with regard to subsequent knowledge transfers' (Hermans and Castiaux 2007, p. 47). However, strict written agreements can restrain researchers from working creatively, which is not conducive to the knowledge creation process. In fact the characteristics of the previous socialization process are important. It should not fail to 'create common perspectives about the collaboration field' (Hermans and Castiaux 2007, p. 47).

With the ongoing research work, the scientific knowledge becomes more complex. At this stage the third level, called combination, comes into play. This means the necessity of fixing the development of the cooperation in written reports (Nonaka et al. 2000). It channels the knowledge creation process and eventually promotes further exchange of tacit knowledge. Nevertheless, at this point the huge conflict of interests between scientific and private stakeholders becomes obvious. The question that arises is which details of the report are to be published and which are not. While industry seeks confidentiality agreements with the scientific party, the researchers aim to present at least parts of the results. In fact the diffusion of public knowledge in the direction of competitors and the scientific community cannot be prevented completely (Hermans and Castiaux 2007). 
In the last step, the helix finishes with what is called 'internalization'. Hermans and Castiaux (2007) subsume under this item the knowledge gains of both parties achieved by means of the cooperation, whereas Nonaka et al. (2000) point out the transfer of the knowledge 'status' from explicit to implicit. Based on data gained by Hermans and Castiaux (2007), this step means progress for both stakeholders, since researchers have access to industrial reality and entrepreneurs can exploit scientific findings. It is important to point out that trust, credibility and social networking are at least equally important effects of the cooperation (Hermans and Castiaux 2007).

\section{Opportunities and threats}

In the previous chapter the trade-off between the goals of entrepreneurs and scientists in the various parts of collaboration was revealed. Against this background it is of interest to look at the conditions for general success or failure of collaboration. For this purpose it must first be defined what kind of collaboration corresponds to the general term Open Innovation.

It should be noted that different forms of knowledge exchange exist, which are clarified in more detail by Perkmann et al. (2013) and their literature review. First of all they point out that the term "commercialization" has attracted major attention in the scientific world and that this kind of channel needs to be distinguished from the concept of "academic engagement". Both concepts are discussed below to clarify the distinction made in the relevant literature as well as in the scientific baseline of this paper.

According to Perkmann et al. (2013), academic engagement can be defined as "knowledge related collaboration by academic researchers with non-academic organisations"(Perkmann et al. 2013, p. 424). Formal activities such as collaborative research, contract research and consulting as well as informal activities such as providing ad-hoc advice and networking with practitioners are subsumed under this kind of interaction. In fact, this channel also incorporates person-to-person interactions.

By contrast, commercialization means generating economic profit from academic inventions. Therefore it does not necessarily encompass person-to-person interaction, since licensing out against the contracted receipt of royalty payments is a formal process. This process depends on the patenting on behalf of academic staff, which expresses a certain desire for exploitation. With regard to organizational matters commercialization may take place by setting up a firm with the objective of commercially exploiting a patented invention, briefly expressed by the term spin-off. Despite these differences the two concepts are linked to each other, since academic engagement precedes commercialization in many cases. For instance, working on common projects may give academic staff an idea for commercially valuable projects and may therefore be a starting point for a spin-off (Perkmann et al. 2013).

In the following the concept of university-industry collaboration is used in the sense of academic engagement, since otherwise person-to-person contacts would not necessarily be included.

In fact such 'successful innovation networks manage to balance dichotomies between diversity and stability in established structures' (Sandberg et al. 2015, p. 47). This means, that there is only a gradual distinction between diversity to foster knowledge creation and diversity to cut boundary-spanning connections. According to Sandberg et al. (2015) and their research work, a large degree of diversity is beneficial to the innovation outcome, 
but in the meantime requires a high level of commitment and patience from all actors involved. Moreover any kind of supervision of a research partnership must take into consideration the motives for participating in the network as well as the desired type of knowledge generation. Whereas partnerships based on codified knowledge transfer can deal with boundary objects such as patents or prototypes, partnerships based on tacit knowledge transfer have to make use of interactional expertise by means of e.g. brokers in the network (Sandberg et al. 2015). Alongside success factors, the discussion of costs and unintended consequences of research partnerships should not be neglected. Although universities are occasionally characterized as ivory towers with a negative connotation, the university-industry connection may be detrimental to the freedom of research. The loss of autonomy of the university may undermine its research performance and thereby influence the innovation system or the innovative performance of firms. Moreover research in the academic world cannot be considered only in economic terms. Otherwise enterprises and their interests would overwhelmingly influence the topics of research and certain fields of research work. Behrens and Gray (2001) have discussed this issue, focusing on the role of the students. They conclude, that their 'results offer little support for those who believe that presence of industry is undermining the research experience students receive and/or eroding core values like academic freedom' (Behrens and Gray 2001, p. 195).

\section{The role of digital media in higher education}

The previous chapters have explored aspects which promote or hinder collaboration and knowledge transfer between universities and industry. This chapter considers possibilities and ideas defining how instruments developed in the e-learning context can foster trust to overcome the gap between the two stakeholders, business and university, on the micro level. The question that arises is how e-learning offerings within higher education may approximate the two stakeholders in spite of their different aims and strengthen the socialization process with regard to the helix discussion (see previous chapter). This refers firstly to the direct knowledge transfer - how can e-learning courses support the knowledge transfer between the two actors, universities and enterprises. As e-learning does not require synchronous and simultaneous attendance of the participants, this results in flexible course formats with new possibilities which fit the time constraints of working people and a supraregional range. Secondly, it reveals potentials in the context of collaborative efforts between universities and employees in continuing higher education and their mediating role for contacts. Finally, online courses are presented as a tool which enhances the knowledge of the actors involved about e.g. the working methods and aims of the other stakeholders in general. Furthermore, the intellectual properties and hence communication and collaboration between the stakeholders will also be enhanced.

\section{OER and MOOCS}

Web 2.0 can be distinguished from the former Web by its openness, the possibility of sharing resources and interaction of the users. 'The Web 2.0 system enhances the pool of knowledge by allowing users to participate, create ideas, and realize their ideas through simple passing of knowledge [..]. It allows users to be innovative' (Kim et al. 2011). Subsequent trends towards open science and open innovation benefit from virtual tools and platforms which have evolved (Gassmann 
et al. 2011). Similar advantages are used for e-learning approaches in the Web 2.0 area. The possibilities of ubiquitous access to learning resources from any location at any time create new possibilities for the target audience of virtual learning offerings and new, interactive, social learning options.

At the beginning of the century the open education resource (OER) movement started. Universities delivered open online access to course content material for several reasons, including enhancing their visibility and providing input for alumni. Based on this movement, the MOOC (Massive Open Online Courses) evolved in 2008 (Daniel 2012). Universities started to offer free online courses to everybody wishing to participate. There are mainly two types of MOOCs, which differ in their pedagogical model. The first MOOC designed by Georg Siemens and Steven Downes at the University of Manitoba, Canada, dealt with the topic 'Connectivism and Connective Knowledge'. MOOCs which follow their theory (Siemens 2012) rely on connectivism and constructivism of knowledge and are called cMOOCs. They do not offer determined, prepared knowledge, but guide learners in contributing their knowledge to the course and reflecting, connecting and integrating knowledge from diverse sources. In contrast, most of the commonly known xMOOCs offered by several universities on platforms like Coursera provide coherent knowledge to the learner. 'Broadly, however, generative vs. declarative knowledge captures the epistemological distinctions between our MOOCs and the Coursera/EDx MOOCs.' (Siemens 2012). This implies a social learning approach for cMOOCs, whereas the xMOOCs predominantly follow an individual learning approach.

Most of the participants of MOOCs are well educated and often already have an academic level (Christensen et al. 2013) - so MOOCs contribute to the lifelong learning process:

Motivations for 18 to 34 years may be closely related to the opportunity to improve their career, moreover, enhance their professional network. Half the respondents indicated that participating in a MOOC enabled them to enhance their professional development and improve their knowledge in the workplace. (White et al. 2014, p. 9).

Some MOOCs explicitly address people with experience in the field of work (e.g. openhpi 2015). So MOOCs are an instrument for universities to become visible for professionals, give them the opportunity to keep their knowledge up to date, and at the same time the participants can obtain an insight into the research activities of the providing departments of the universities and recognize connections with their field of work. Depending on the grade of interaction between the participants and with the course providers during the MOOC, MOOCs are also an opportunity to generate weak ties and start networking effects (Granovetter 1973). This would be particularly fostered in cMOOCs (Saadatmand and Kumpulainen 2014) - so xMOOCs increasingly implement interactive elements to support learning communities. In addition, companies are working together with academic institutions to enhance corporate learning through MOOCs prepared and conducted collaboratively, as was the case in German-speaking countries with the MOOC "corporate learning 2.0" ("Corporate Learning 2.0 MOOC CL20' n.d.) in September 2016 and the MOOC "Hands on Industrie 4.0" in April 2016 ('Hands on Industrie 4.0' 2016). A European study concerning the benefits of MOOCs for corporate institutions also revealed -besides the educational effects - potential for knowledge sharing between HEI and business by means of networking effects. 
Nevertheless some work remains to be done according to the authors with regard to some reservations due to prior negative experiences with eLearning and the quality of free-of-charge courses (Driha, Friedl \& Jansen, 2017).

To sum up, MOOCs can be an option for professionals to keep up with rapidly changing and developing knowledge. Furthermore, MOOCs provide an insight into universities' research activities and contacts who can be addressed for industry-university cooperation and subsequent innovation. To foster the network effect, MOOCs should provide social learning opportunities and regard the linkage to the work field activities of the participants as a relevant resource for the knowledge creation. 'The MOOC design could also exploit the existing knowledge of its professional learners as a core course resource. Professional learners bring a wealth of experience to their learning.' (Milligan and Littlejohn 2014).

\section{Continuing higher education}

The information and knowledge society is shaped by rapidly changing knowledge. This implies that lifelong learning processes of employees are becoming increasingly important for the success of firms. Besides the MOOCs mentioned above, continuing higher education offered by universities is a way for employees to gain deeper insights into actual, theoretical knowledge. Blended learning formats which combine distance learning with on-campus learning phases are a widespread format for continuing higher education. The possibility of combining professional life with academic learning activities is the backbone of continuing higher education. To foster the adaption of newly learned theoretical knowledge to the field of work (and therefore to increase innovation potential), a strong connection between the formal learning in the education context and the informal or non-formal work field context is required (Vogt 2012). The Seamless Learning Model (SLM) as described by Wong (Wong 2012) subsumes scenarios that comprise learning in different situations, at different times, in different locations, alone and in groups and face-to-face, as well as through media transfer. At the same time the SLM emphasizes the necessary linkage between informal or non-formal learning and formal learning, just as between physical learning and digital learning. Furthermore the SLM incorporates the need for flexibility, considering the heterogeneous situations of lifelong learners, as well as the possibility of relating the work field experience to theoretical knowledge and vice versa (Eube \& Vogt, 2016). Thanks to digital media, the integration of different learning places into a personal learning environment is possible and enhances the acceptance and outcome of continuing academic education. Maschwitz (2014) recommends cooperation between corporations and public universities for the continuing higher education programme conception for several reasons, e.g. exchange of theory and practice and knowledge transfer. At the same time she emphasizes the necessary changes in education policy and cooperation culture which would foster these collaborations. Similar benefits of knowledge transfer are quoted for enterprises and universities when collaborating on study course development (Kock et al. 2000).

Several actors benefit from continuing higher education. Firstly the individual can improve his or her opportunities for career progression, salary improvements and so forth. Industry gains access to knowledge which can result in innovation potential, and last but not least the university gains insight into business needs and can refine its research (Slotte and Tynjälä 2003). When industry and university collaborate in offering 
continuing academic education, they will initially work together without focusing on aspects such as different goals of cooperative research projects. To organize the collaboration for development and realization of a study program, the actors of the universities and the industry communicate and have to bridge the cultural gap (for details of the patterns of the collaboration process see Maschwitz 2014). Therefore relational involvement will increase and support trust, the first step in the helix (socialization) will be facilitated, and the collaboration for education can therefore contribute to further cooperation and knowledge transfer.

\section{Online courses referring to innovation collaboration}

In addition to these possibilities of fostering the networking between universities and industry during further education of employees by MOOCs or by continuing academic education, the government can directly implement online courses to educate the stakeholders and prepare them for collaboration. Often there is a lack of information about the general working methods and goals of the other stakeholder (Blunck and Bradler 2009). Online courses which inform interested stakeholders about these differences can dismantle potential communication barriers in advance. The project SUPORT as part of the European Erasmus Lifelong Learning Program analyzed pre-knowledge needs of small and medium enterprises (SME) and higher education institutions (HEI) and is developing an e-learning programme which will meet these requirements (SUPORT 2015). Everybody interested can learn about the other stakeholder's characteristics. A similar approach - supporting potential partners in university-industry collaboration with valuable knowledge to prevent pitfalls - has been the goal of the Online General Course on Intellectual Properties in Brazil (de Lima Hatschbach et al. 2014). The topic of the course is knowledge about intellectual property, as information about the legal boundary condition concerning intangible assets is a prerequisite for collaboration and knowledge transfer between universities and industry. The free online course was funded by the Ministry of Development, Industry and Trade and refers to national cases and Brazilian reality; it is held in Portuguese.

The authors identified three groups who benefit from the course: students, universities and research centres as well as industries and companies. While the students obtain free access to national, specific, specialized content and social networks with experts, universities and research centres gain access to staff with the necessary specific skills. Last but not least, industry and companies benefit "since the greater the knowledge of intellectual property by the society, better is the communication established between all actors of the national innovation system" (de Lima Hatschbach et al. 2014).

\section{Policy implications}

This paper has argued that collaboration between economic and scientific actors fosters innovative performance, which reflects the general state of the art with regard to evolutionary economic studies and approaches such as NIS, OI or the Triple Helix. Consequently policy which focuses on the relationship between the different actors - state, entrepreneurship and university - should be promoted. One strategy already frequently followed is to link financial subsidies by the state with the condition of collaboration. Nevertheless, the devil is in the details when certain projects apply for financial 
support. The question that arises here is which projects should be promoted to guarantee sustainable economic development, and moreover which instruments should be put into practice to gain the desired results. Rijnsoever et al. (2014) have tried to answer this question by focusing on technology diversity as an outcome and elaborate that 'technological diversity is important to achieve long-term technological progress as diversity fosters recombinant innovation and renders undesirable lock-ins less likely' (van Rijnsoever et al. 2014, p. 1094). Diversity is not effectively increased by just subsidizing more collaborative projects. Instead projects should have a limited number of partners, but different ones, and should have not too many ties within the current innovation system (van Rijnsoever et al. 2014, p. 1105). Rijnsoever et al. (2014) thereby underline the general conclusion that the government needs to look for certain success factors with regard to financial subsidies. Simply financing collaboration ignores the complex conditional environment for innovative performance. This paper aims to contribute to this discussion by relating the theoretically conceptualized demands to the offers from new media.

Firstly, this paper follows the thesis that network structures on the governmental level foster knowledge transfer on the micro level. Even though empirical research work remains to be done via case studies, the comparative research work on the two countries Chile and Mexico performed by Becker (2014) has revealed conceptual differences between the regulations of innovation policy in the two countries. Although both countries have installed specific councils for innovation policy, innovation policy is organized in different ways, which may be an explanatory variable for the different innovative outcome of the two countries Becker (2014). Nevertheless, there is a gap to be filled between the regulation of innovation policy on the macro level and a certain research partnership or innovation network on the micro level. Two points of interest appear important to open this black box.

On the one hand trust fulfils a crucial role for various reasons. Firstly the tradeoff between scientists and entrepreneurs may be mitigated through trust-building measures. Secondly tacit knowledge transfer becomes crucial for innovative effects and trust is a requisite for such an exchange. Thirdly the tightrope between diversity and stability can be managed better. Fourthly trust becomes the independent variable for the general stability of networks, which seems to be fruitful for knowledge exchange. On the other hand intermediate actors, who act as brokers between science and industry and can therefore develop trust-building measures, should not be neglected. Accordingly the two aspects of brokers and trust are closely correlated.

With regard to this, in the authors' view Web 2.0 applications fulfil crucial functions. With the European project SUPORT already mentioned or the Chilean platform Innoversia.net, different forms of online marketplaces are established for the exchange of knowledge and expertise. These can fulfil the function of brokers, whose promotion by the state might be expedient. Moreover all measures and techniques which support the approximation of science and industry should not be neglected. Therefore the emerging development towards MOOCs in the context of lifelong learning might be a starting point and another aspect to be promoted. For the same reason the policy framework for continuing higher education should take into consideration the close collaboration between industry and universities during 
both the concept phase and the implementation period. Of course the discussion about the pros and cons of MOOCs cannot be disregarded and there are still voices that alert the community about the convergence of science and industry.

Summing up, trust-developing brokers like marketplaces for the exchange of knowledge are useful tools for promoting research partnerships on the micro level. Nevertheless, it is necessary to bring industry and science closer through a policy approach on the macro level which turns out to be less hierarchical. In the sense of social networks, the different actors in a National Innovation System have to be brought together to decide e.g. about technical trajectories and research focuses and this promises to be successful. Otherwise certain measures on the micro level might founder.

One corresponding measure could be to set up a council for innovation with a good balance between representatives of the government, industry and science. The OECD has already developed a list of criteria to benchmark the national councils of different countries (Organisation for Economic Cooperation and Development 2007). Nevertheless this is not a blueprint for innovation policy, as Orlowski points out with regard to its analysis of the interlocking directorate network surrounding the Council for Innovation and Growth and the Industry-Science Research Alliance in Germany (Orlowski 2012).

\section{Policy and its implementation}

This paper argues in favour of university-industry cooperation and has underlined the role of innovation policy to foster its dynamics. In Germany, for instance, the policy launched impetuses to increase the feasibility of such cooperation in the 1980s and 1990s. Within universities transfer sub-organizations have been installed to fulfil the task of bringing university and industry closer. Meier and Krücken (2011) consider this recent development critically and even question this institutional innovation. According to their empirical results, these institutions within universities cannot fulfil the desired outcome. In fact such transfer organizations fail especially if implicit know-how is necessary for the cooperation. They do not dispose of the knowledge for each cooperation arrangement and are therefore often disregarded by the industry as well as by university researchers. Instead, personal contacts between the different stakeholders remain crucial for generating momentum in cooperation, or to put it in another way, institutional reorganizations are no substitute for the necessary trust-building measures. This example is therefore quoted within this context, since these transfer sub organizations were realized in Germany due to political constraints. The universities have not internalized this policy wish and have instead proceeded to conduct business as usual (Meier and Krücken 2011).

Trust-building measures like those performed by MOOCs or life-long-learning approaches are useful, even if these are in fact side effects and not the original intention. Moreover these digital learning concepts stem from universities themselves and may therefore contribute implicitly to the 'third academic mission' of universities and a new self-understanding. The main task of policy within this context seems to be to accompany this process smoothly by moderating between the two stakeholders, universities and entrepreneurs. 
Authors' contributions

CE provided the chapter 'The role of digital media in higher education' and BAB wrote the other paragraphs. Both authors read and approved the final manuscript.

\section{Competing interests}

The authors declare that they have no competing interests.

\section{Publisher's Note}

Springer Nature remains neutral with regard to jurisdictional claims in published maps and institutional affiliations.

Received: 24 July 2017 Accepted: 12 March 2018

Published online: 03 April 2018

\section{References}

Barnes, T., Pashby, I., \& Gibbons, A. (2002). Effective university - industry interaction. A Multi-Case Evaluation of Collaborative $R \&$ D Projects, 20(3), 272-285.

Becker, B. A. (2014). Netzwerk versus Hierarchie. Bochum: Stärken und Schwächen der Innovationspolitik in Schwellenländern anhand eines Ländervergleichs von Chile und Mexiko.

Behrens, T. R., \& Gray, D. O. (2001). Unintended consequences of cooperative research: Impact of industry sponsorship on climate for academic freedom and other graduate student outcome. Research Policy. A Journal Devoted to Research Policy, Research Management and Planning, 30(2), 179-199.

Benz, A., \& Dose, N. (2010). Von der Governance-Analyse zur Policytheorie. In A. Benz \& N. Dose (Eds.), Governance Regieren in komplexen Regelsystemen (pp. 251-276). Wiesbaden: VS, Verl. für Sozialwiss.

Blunck, D., \& Bradler, M. (Eds.). (2009). Barriers to knowledge transfer - an evaluative study (1. Aufl). Heidelberg: C.F. Müller.

Chaminade, C., \& Edquist, C. (2010). Rationales for Public Policy Intervention in the Innovation Process: Systems of Innovation Approach. In R. Smits, S. Kuhlmann, \& P. Shapira (Eds.), The theory and practice of innovation policy : an international research handbook (pp. 95-114). Cheltenham; Northampton: Edward Elgar.

Chesbrough, H. W. (2008). Open innovation. Oxford: Oxford Univ. Press.

Chesbrough, H. W., Vanhaverbeke, W., \& West, J. (2006). Open innovation. Oxford: Oxford University Press.

Christensen, G., Steinmetz, A., Alcorn, B., Bennett, A., Woods, D., \& Emanuel, E. J. (2013). The MOOC Phenomenon: Who Takes Massive Open Online Courses and Why? (SSRN Scholarly Paper No. ID 2350964). Rochester: Social Science Research Network Retrieved from http://papers.ssrn.com/abstract=2350964.

Cockburn, I. M., \& Henderson, R. M. (2000). Publicly funded science and the productivity of the pharmaceutical industry Innovation Policy and the Economy, 1, 1-34. https://doi.org/10.1086/ipe.1.25056140.

Cohen, W. M., Nelson, R. R., \& Walsh, J. P. (2002). Links and Impacts - The Influence of Public Research on Industrial R\&D. Management Science: Journal of the Institute for Operations Research and the Management Sciences, Jg., 2002(1), 1-23. https://doi.org/10.1287/mnsc.48.1.1.14273.

Corporate Learning 2.0 MOOC - CL20. (n.d.). Retrieved 1 May 2015, from https://colearnall.wordpress.com/2015/03/01/ corporate-learning-2-0-mooc-cl20/.

Daniel, S. J. (2012). Making sense of MOOCs: Musings in a maze of myth, Paradox and possibility. Retrieved from http://www.tonybates.ca/wp-content/uploads/Making-Sense-of-MOOCs.pdf.

de Jong, J. P. J., Vanhaverbeke, W., Kalvet, T., \& Chesbrough, H. (2008). Policies for open innovation. Theory, framework and cases. Retrieved from www.eurosfaire.prd.fr/../1246020063_oipaf_final_report_2008.pdf.

de Lima Hatschbach, M. H., Castello Guimaraes, A., \& Alves Lima, A. (2014). General course on intellectual property: an example of developing effective and sustainable E-learning course in Brazil (pp. 121-127).

Driha, O. M., Friedl, C., \& Jansen, D. (2017). Identification of opportunities of MOOCs for the business community (organisations) (BizMOOC - BizMOOC - Knowledge Alliance to enable a European-wide exploitation of the potential of MOOCs for the world of business No. 1.3a). EU Erasmust.

Etzkowitz, H., \& Leydesdorff, L. (2000). The dynamics of innovation: from National Systems and "Mode 2" to a triple Helix of university-industry-government relations. Research Policy, 29(2), 109-123. https://doi.org/10.1016/S0048-7333(99)00055-4.

Eube, C., \& Vogt, S. (2016). Walk this way -Konzepte der Stadtplanung für die (Aus-) Gestaltung von Seamless-LearningRäumen. Zeitschrift Für Hochschulentwicklung. Retrieved from http://www.zfhe.at/index.php/zfhe/article/view/967.

Fabrizio, K. R. (2006). The use of university research in firm innovation. In H. W. Chesbrough, W. Vanhaverbeke, \& J. West (Eds.), Open innovation (pp. 134-161). Oxford: Oxford University Press.

Freeman, C. (1991). Networks of innovators - A synthesis of research issues. Research Policy, 20(5), 499-514.

Gassmann, O., \& Enkel, E. (2006). Open Innovation. [Wettbewerb]. Zeitschrift Führung Organisation. Zfo, Jg, 2006(3), 132-139.

Gassmann, O., Widenmayer, B., Friesike, S., \& Schildhauer, T. (2011). Opening Up Science: Towards an Agenda of Open Science in Industry and Academia. SSRN Electronic Journal. https://doi.org/10.2139/ssrn.2091122.

Granovetter, M. S. (1973). The strength of weak ties. American Journal of Sociology, 78(6), 1360-1380.

Hands on Industrie 4.0. (2016). Retrieved 24 August 2016, from https://mooc.house/courses/industrie40-2016.

Hermans, J., \& Castiaux, A. (2007). Knowledge creation through university-industry collaborative research projects. Electronic Journal of Knowledge Management, 2007(1), 43-54.

Hollingsworth, J. R. (2000). Doing institutional analysis: Implications for the study of innovations. Review of International Political Economy, 7(4), 595-644.

Hollingsworth, J. R., Schmitter, P. C., \& Streeck, W. (1994). Governing capitalist economies. New York: Oxford University Press.

Kaiser, R. (2008). Innovationspolitik : Staatliche Steuerungskapazitäten beim Aufbau wissensbasierter Industrien im internationalen Vergleich (1. Aufl.). Baden-Baden: Nomos.

Kim, K. Altmann, J., \& Hwang, J. (2011). Measuring and analyzing the openness of the Web2.0 service network for improving the innovation capacity of the Web2.0 system through collective intelligence. In T. Bastiaens, U. Baumöl, 
\& B. Krämer (Eds.), On Collective Intelligence (Vol. 76, pp. 93-105). Berlin Heidelberg. Retrieved from: Springer. https://doi.org/10.1007/978-3-642-14481-3_8.

Kock, N., Auspitz, C., \& King, B. (2000). Using the web to enable industry-university collaboration: an action research study of a course partnership. Informing Science, 3(3), 157-165.

Lee, Y. S. (2000). The sustainability of university-industry research collaboration - an empirical assessment. The Journal of Technology Transfer, Jg, 2000(2), 111-134. https://doi.org/10.1023/A:1007895322042.

Lundvall, B.-A. (1992). National systems of innovation: towards a theory of innovation and interactive learning. London; New York: Pinter Publishers; Distributed exclusively in the USA and Canada by St. Martin's Press.

Lütz, S. (2006). Governance in der politischen Ökonomie. In S. Lütz (Ed.), Governance in der politischen Ökonomie: Struktur und Wandel des modernen Kapitalismus (pp. 13-56). Wiesbaden: VS Verlag für Sozialwissenschaften.

Maschwitz, A. (2014). Cooperation between public universities and corporations in the field of professional study programs. Stockholm: Presented at the 2014 EFMD Higher Education Research Conference Retrieved from https:/www.researchgate.net/publication/ 274577811_Cooperation_between_public_universities_and_corporations_in_the_field_of_professional_study_programs.

Meier, F., \& Krücken, G. (2011). Wissens- und Technologietransfer als neues Leitbild? Universitäts-WirtschaftsBeziehungen in Deutschland. In B. Hölscher \& J. Suchanek (Eds.), Wissenschaft und Hochschulbildung im Kontext von Wirtschaft und Medien (pp. 91-108). Wiesbaden. Retrieved from. https://doi.org/10.1007/978-3-531-92648-3.

Meissner, D., \& Kotsemir, M. (2016). Conceptualizing the innovation process towards the 'active innovation paradigm'trends and outlook. Journal of Innovation and Entrepreneurship : JIE, 5(14), 1-18.

Milligan, C., \& Littlejohn, A. (2014). Supporting professional learning in a massive open online course. The International Review of Research in Open and Distributed Learning, 15(5) Retrieved from http:/wwww.irrodl.org/index.php/irrodl/article/view/1855.

Nelson, R. R. (1993). National innovation systems. New York [u.a.]: Oxford Univ. Press.

Newell, S., \& Swan, J. (2000). Trust and inter-organizational networking. Human Relations. Towards the Integration of the Social Sciences, 53(10), 1287-1329.

Niosi, J., Saviotti, P., Bellon, B., \& Crow, M. (1993). National systems of innovation: in search of a workable concept. Technology in Society, 15(2), 207-227. https://doi.org/10.1016/0160-791X(93)90003-7.

Nonaka, I., Toyama, R., \& Konno, N. (2000). SECl, Ba and leadership: a unified model of dynamic knowledge creation. Long Range Planning: International Journal of Strategic Management, 33(1), 5-34.

openhpi. (2015). Automated Visual Software Analytics. Retrieved 6 August 2015, from http://open.hpi.de/courses/ softwareanalytics 2015

Organisation for Economic Cooperation and Development, O. (2007). OECD Reviews of Innovation Policy: Chile. Paris. Retrieved from. https://doi.org/10.1787/9789264037526-en.

Orlowski, M. (2012). The Politics of Innovation: Analysing Inter-organisational Networks Around German Innovation Policy Advisory Bodies. In J. M. Bauer, A. Lang, \& V. Schneider (Eds.), Innovation policy and governance in high-tech industries the complexity of coordination (pp. 155-176). Berlin; New York: Springer. Retrieved from. https//doi.org/10.1007/978-3-642-12563-8.

Ortiz, M. (2013). Varieties of innovation systems. Frankfurt am Main [u.a.]: Retrieved from http://d-nb.info/1028317549/04

Perkmann, M., Tartari, V., McKelvey, M., Autio, E., \& Broström, A. (2013). Academic engagement and commercialisation. A Review of the Literature on University-Industry Relations, 42(2), 423-442.

Perkmann, M., \& Walsh, K. (2007). University-industry relationships and open innovation: Towards a research agenda. International Journal of Management Reviews, 9(4), 259-280. https://doi.org/10.1111/j.1468-2370.2007.00225.x.

Poyago-Theotoky, J., Beath, J., \& Siegel, D. S. (2002). Universities and fundamental research - reflections on the growth of university-industry partnerships. Oxford Review of Economic Policy, 18(1), 10-21.

Rayna, T., \& Striukova, L. (2015). University-industry knowledge exchange: An exploratory study of open innovation in UK universities. European Journal of Innovation Management, 18(4), 471-492.

Saadatmand, M., \& Kumpulainen, K. (2014). Participants' perceptions of learning and networking in connectivist MOOCs. Journal of Online Learning and Teaching, 10(1), 16-30.

Sandberg, J., Holmström, J., Napier, N., \& Levén, P. (2015). Balancing diversity in innovation networks. European Journal of Innovation Management, 18(1), 44-69.

Siemens, G. (2012). What is the theory that underpins our moocs? Retrieved from http://www.elearnspace.org/blog/ 2012/06/03/what-is-the-theory-that-underpins-our-moocs/.

Slotte, V., \& Tynjälä, P. (2003). Industry-university collaboration for continuing professional development. Journal of Education and Work, 16(4), 445-464. https://doi.org/10.1080/1363908032000093058.

SUPORT. (2015). Welcome to SUPORT SME University Partnership Online Resource \& Training. Retrieved 7 August 2015, from http://www.suport-project.eu/.

van Rijnsoever, F. J., van den Berg, J., Koch, J., Hekkert, M. P., Dynamics of Innovation Systems, \& Innovation Studies. (2014). Smart innovation policy: How network position and project composition affect the diversity of an emerging technology. Retrieved from http://dspace.library.uu.nl:8080/handle/1874/308826.

Vogt, S. (2012). Lifelong learning in the long tail age - The educational technology challenge of distance learning. Journal of Lifelong Learning Society, 23-37.

Werle, R. (2012). Institutions and Systems: Analysing Technical Innovation Processes from an Institutional Perspective. In Bauer et al. (Eds.), Innovation Policy and Governance in High Tech Industries (pp. 23-48). Berlin; New York: Springer.

White, S., Davis, H., Dickens, K. P., Leon, M., \& Sanchez Vera, M. M. (2014). MOOCs: What motivates the producers and participants? Communications in Computer and Information Science. Retrieved from http://eprints.soton.ac.uk/370440/.

Wong, L.-H. (2012). A learner-centric view of mobile seamless learning. British Journal of Educational Technology, 43(1), E19-E23. https://doi.org/10.1111/j.1467-8535.2011.01245.X.

Worasinchai, L., Ribiere, V. M., \& Arntzen, A. A. B. (2008). Working knowledge, the university-industry linkage in Thailand: Concepts and issues. Vine, 38(4), 507-524 https://ub-proxy.fernuni-hagen.de/login?url=http://dx.doi.org/10.1108/03055720810917741.

Yokura, Y., Matsubara, H., \& Sternberg, R. (2013). R\&D Networks and Regional Innovation: A Social Network Analysis of Joint Research Projects in Japan. Area. Royal Geographical Society, 45(4), 493-503.

Zucker, L. G. (1986). Production of trust: institutional sources of economic structure, 1840-1920. In B. M. Staw \& L. L. Cummings (Eds.), Research in organizational behaviour : an annual series of analytical essays and critical reviews (pp. 53-111). Greenwich Conn.; London: JAI Press. 